\title{
ON THE DEATH OF THE EMPRESS FAUSTA
}

\author{
By DAVID WOODS
}

Fausta, or Flavia Maxima Fausta to call her by her full name, was the daughter of one western emperor, Maximianus Herculius (286-305), the sister of another, Maxentius (306-12), and the wife of a third, Constantine I (306-37). ${ }^{1}$ She was married to Constantine in 307, and bore him at least five children from 316 onwards, three sons (Constantine, Constantius, and Constans), and two daughters (Constantina and Helena).$^{2}$ Following his defeat of his rival Licinius at the battle of Chrysopolis in 324, and the unification of the empire under his rule as the sole Augustus once more, Constantine honoured with the title of Augusta both his wife Fausta and his mother Helena, as is revealed by the issue of coins in their names each with this title. ${ }^{3}$ However, tragedy struck in 326 when Constantine appears to have executed first his eldest son Crispus, then Fausta herself. The reason for these executions, and the extent to which these deaths were related, has attracted a great deal of debate. Yet more remains to be said about the manner in which Fausta died, which may well provide an important clue as to the full circumstances of her death, whether she was executed, died by accident, or committed suicide even. Thus, it is my intention here, firstly, to offer a new explanation for the manner of her death, and secondly, to draw attention to an overlooked allusion to her death in a late Latin source, the Historia Augusta.

\section{How did Fausta die?}

Let us begin with a brief catalogue of the more important sources for the deaths of Crispus and Fausta, that is, those sources which do not simply note the occurrence of these executions, but seek to provide some detail also concerning their full circumstances: ${ }^{4}$

(i) The anonymous author of the Latin Epitome de Caesaribus, composed c.396, wrote as follows (Epit. 41.11-12):.5

But when Constantine had obtained control of the whole Roman Empire by means of his wondrous success in battle, he ordered his son Crispus to be put to death, at the 
suggestion of his wife Fausta, so they say. Then he killed his wife Fausta by hurling her into boiling baths (in balneas ardentes coniectam), when his mother Helena rebuked him with excessive grief for her grandson.

(ii) According to the surviving epitome of his work by the 9th-century scholar Photius of Constantinople, the Arian ecclesiastical historian Philostorgius, who wrote c.425, claimed that $(H E 2.4):{ }^{6}$

... Constantine was induced by the fraudulent artifices of his step-mother to put his son Crispus to death; and afterwards, upon detecting her in the act of adultery with one of

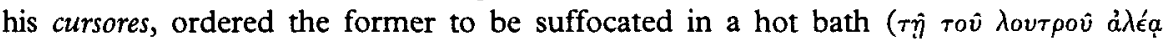

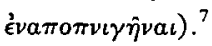

(iii) Sidonius Apollinaris, bishop of Arvernum in Gaul c.471-87, wrote to a friend in praise of his poetry, stating that (Epist. 5.8.2): ${ }^{8}$

... no greater power of satiric suggestion was shown by the consul Ablabius when in a couple of verses he stabbed at the life and family of Constantine and put his tooth into them with this distich posted up secretly on the door of the palace:

Who would now want the golden age of Saturn?

Ours is a diamond age - of Nero's pattern.

He wrote this, of course, because the aforesaid Augustus had almost simultaneously got rid of his wife Fausta with a hot bath (calore balnet) and his son Crispus with cold poison. ${ }^{9}$

(iv) A pagan historian of the early 6th-century, Zosimus, probably working at Constantinople, did little more than abbreviate the work of a late 4th-century pagan historian, Eunapius, and reported that ( $H N$ 2.29.2): $:^{10}$

Without any consideration for natural law he [Constantine] killed his son, Crispus, who, as I have related before, had been considered worthy of the rank of Caesar, on suspicion of having had intercourse with his stepmother, Fausta. And when Constantine's mother, Helena, was saddened by this atrocity and was inconsolable at the young man's death, Constantine as if to comfort her, applied a remedy worse than the disease: he ordered a

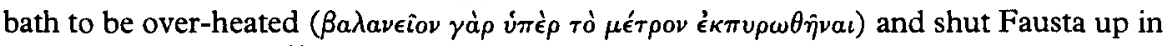
it until she was dead. ${ }^{11}$

(v) The Passion of Artemius, a largely fictitious account of the trial under the emperor Julian of the general $(d u x)$ Artemius, which depends for much of its historical information on the work of Philostorgius above, and was probably written in the 8th century by the theologian John of Damascus, attributes to Artemius a speech which includes the following (Art. Pass 45): ${ }^{12}$ 
Constantine did kill his wife Fausta - and rightly so, since she had imitated Phaedra of old, and accused his son Crispus of being in love with her and assaulting her by force, just as Phaedra accused Theseus' son Hippolytus. And so according to the laws of nature, as a father he punished his son. But later he learnt the truth and killed her as well, exacting the most righteous penalty against her.

(vi) Writing in the 12 th-century, although with access to early 4 th-century sources, the Greek historian Zonaras claimed (Epit. 13.2.38-41): ${ }^{13}$

His [Crispus'] stepmother Fausta was madly in love with him but did not easily get him to go along. She then announced to his father that he [Crispus] loved her and had often attempted to do violence to her. Therefore, Crispus was condemned to death by his father, who believed his wife. But when the emperor later recognized the truth he punished his wife too because of her licentiousness and the death of his son. Fausta was

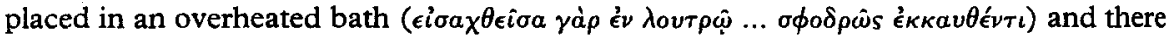
found a violent end of her life. ${ }^{14}$

So what do modern commentators make of these unsavoury allegations? Obviously something terrible happened. Not only were Crispus and Fausta executed, but their memory was also condemned (damnatio memoriae). Their names were erased from public inscriptions, and the literary record was similarly affected. ${ }^{15}$ Eusebius of Caesarea, for example, revised later copies of his Ecclesiastical History in order to omit earlier material in praise of Crispus, and his Life of Constantine which he composed c.338 makes no mention whatsoever of either Crispus or Fausta. ${ }^{16}$ Yet there has been marked reluctance in recent times to accept the allegations of a sexual scandal, that Crispus and Fausta had become embroiled in an intimate relationship for which they both paid with their lives. ${ }^{17}$ Hence P. Guthrie, for example, has argued that the execution of Crispus was a dynastic murder by Constantine in order to remove his eldest and illegitimate son from the succession in favour of his three legitimate sons by Fausta. ${ }^{18}$ This has been ably refuted by $\mathrm{H}$. A. Pohlsander who, among his other arguments, pointed out that the appointment of Crispus to the rank of Caesar in $317 \mathrm{had}$ already proved his eligibility for the rank of Augustus, and that Constantine was unlikely to regard illegitimacy as a bar to succession, being illegitimate himself also. ${ }^{19}$ Yet argument and counter-argument both suffer serious flaws, the former more so, in that it is not at all clear that Crispus and Constantine were actually illegitimate. Many scholars now deny this. ${ }^{20}$ More importantly, this theory does not explain why Constantine had Fausta executed also, nor the unusual manner of her death. In brief, it pays too little attention to what the sources themselves actually say in this matter. 
Another theory has some merit in that it does at least accept that there was a real connection between the deaths of Crispus and Fausta. According to N. J. E. Austin, Crispus had his future predicted, and Fausta reported this to Constantine as a conspiracy against his rule. ${ }^{21} \mathrm{He}$ executed Crispus immediately, but soon repented of his haste when he discovered that there was little basis to her allegation. Consequently, he held her responsible for Crispus' death, and executed her also. Again, this explanation of events pays too little attention to the testimony of the sources themselves. It ignores the allegations of adultery, nor does it sufficiently explain the unusual manner of Fausta's death. Furthermore, as J. W. Drijvers notes, it does not explain why the condemnation of Crispus' memory was not reversed when it emerged that he was innocent. ${ }^{22}$ If Fausta had been killed because her charge against Crispus was discovered to be false, then his memory ought to have been restored and commemorated accordingly. But this did not happen.

The reasons why some scholars have been so reluctant to accept the allegation of a sexual relationship between Crispus and Fausta vary somewhat. T. D. Barnes, for example, excluded the possibility of a sexual relationship between them on the basis that 'Crispus normally resided at Trier, far from his stepmother, who lived at his father's court'. ${ }^{23}$ Hence his claim that 'Fausta or her agents (my emphasis) must have played a large role in securing Crispus' condemnation', playing down the possibility of any physical contact between the two. Alternatively, others have been deterred by the similarity of the alleged relationship between Fausta and Crispus to that between Phaedra and Hippolytus, as if the story of their relationship was an invention simply with this myth as its model. ${ }^{24}$ Others again have been influenced more by the apparent origin of this allegation than by the nature of the allegation itself. For it is possible that all the surviving sources in this matter depend upon a single original source only, a pagan source which was implacably opposed to Constantine because of his rejection of Rome's traditional cults and his espousal of Christianity. The fact that Zosimus explicitly links the murders of Crispus and Fausta to Constantine's conversion to Christianity serves to fuel this scepticism. According to Zosimus (HN 2.29.3-5), when the full impact of his deeds had dawned upon him, Constantine had approached the pagan priests and sought purification for his sins. When these told him that no purification was possible for these sins, an Egyptian from Spain, normally identified as bishop Ossius of Cordova, informed him to the contrary, that Christ would forgive all sins. ${ }^{25}$ Hence Constantine became a Christian. The polemical nature of 
this story, and the tradition which it represents, is such that Drijvers has rejected it in entirety, claiming that 'only one option is left and that is to conclude that Constantine's motives for killing his son and wife will always remain unknown, in spite of the many ingenious suppositions of historians'. ${ }^{26}$ Yet while one does not doubt that pagan historians hostile to Constantine rejoiced to recount his cruel execution of Crispus and Fausta, it does not necessarily follow that one of their number must have invented the story of their adultery also. The silence of the earliest Christian authors on this topic is sufficient guarantee that a serious scandal really did lie behind their deaths. Pagan tradition simply preserved that which most Christians were all too eager to forget, and eventually set it to serve a new polemical purpose.

So why was Fausta killed in the unusual manner alleged? All the surviving sources who care to comment on the exact manner of her death, Greek and Latin, pagan or Christian, seem to agree on its location, in a bath or bathroom, even if they do not agree upon, or care to mention even, the nature of her offence. There is strong agreement also that it was the heat of the bath or bathroom which was the immediate cause of her death. However, it remains unclear whether Fausta suffocated to death in the steam, or was scalded to death by the water itself. Of our ancient sources, only Philostorgius, or his epitomator rather, favours death by suffocation, and the rest remain sufficiently vague to allow of either possibility. The problem is that the terms used to describe the exact location of Fausta at her death (balneum, $\beta a \lambda a \nu \epsilon i o \nu$, $\lambda o v \tau \rho o ́ v)$ can all refer either to the bath itself or to the room within which this bath was situated. Unless the verb used in association with these terms is itself specific, that she suffocated, drowned or was burned to death, we must remain in the dark as to the exact manner of her death. Yet while Philostorgius is quite clear that Fausta suffocated to death, it is important to remember that his original account has not itself survived, but only an epitome of the same by Photius. There must be some doubt, therefore, whether Philostorgius himself actually stated that Fausta suffocated, or Photius just assumed this upon reading Philostorgius' description of the cause of death, the heat of her bath or bathroom. It is no surprise, therefore, that modern commentators seem unable to agree on the exact manner of her death either. Drowning, suffocation by steam, and burning or scalding to death, have all had their advocates. ${ }^{27}$

One scholar considers Fausta's confinement to an overheated bath (or bathroom) as an ordeal to find out whether she had committed adultery with Crispus. ${ }^{28}$ It was a means of interrogation first, then execution. Yet 
this treatment seems no less extraordinary whether one considers it a form of interrogation by torture only, or a deliberate method of execution. A number of different forms of capital punishment were practised during the 4 th century. These included beheading, burning at the stake, and dismemberment, as well as more inventive punishments such as suffocation over a slow fire, or the pouring of molten lead down the victim's throat. ${ }^{29}$ However, no other case is known where the victim was sentenced to death in a bath. Indeed, there are no known instances of the application of the death penalty for adultery under Constantine, other than in the case of Crispus and Fausta, and although adulterers were often punished with death during later reigns, beheading seems to have been the favoured punishment. ${ }^{30}$ Hence the suggestion that Fausta committed suicide, even if it was 'suicide under compulsion', has some merit, and the unusual manner of her death may well have been suggested to her in order to emphasize its 'voluntary' nature. ${ }^{31}$ One notes, for example, that during the investigation of various sexual crimes at Rome c.368, a certain Hesychia suffocated herself on her feather bed rather than face interrogation. ${ }^{32}$ This is reminiscent of the claim that Fausta suffocated to death also, although it may be that Hesychia's choice was dictated more by the absence of other means rather than a preference for suffocation itself.

A third possibility is that Fausta died by accident instead. In his ecclesiastical history Theodoret, bishop of Cyrrhus 423-66, tells of a number of encounters which took place at Antioch between the Syrian monk Aphraates and the emperor Valens (364-78), or members of his staff, including the following cautionary tale ( $H E$ 4.23):

One of the grooms of the imperial bedchamber, who threatened the godly man [Aphraates] somewhat more violently, met with the following fate. He was entrusted with the charge of the bath, and immediately after this conversation he came down to get it ready for the emperor. On entering he lost his wits, stepped into the boiling water before it was mixed with the cold, and so met his end. The emperor sat waiting for him to announce that the bath was ready for him to enter, and after a considerable time had gone by he sent other officers to report the cause of the delay. After they had gone in and looked all about the room they discovered the chamberlain slain by the heat, and lying dead in the boiling water. ${ }^{33}$

While this tale serves to illustrate that fatal accidents were possible when preparing a hot bath, it also shows that these were far more likely to happen to their servants than to the members of the imperial family themselves. It seems unlikely, therefore, that Fausta would have died in such a manner. One should remember at this point, though, that baths often served purposes other than those of hygiene or pleasure, being 
regarded as beneficial for a variety of ailments also. ${ }^{34}$ It is said, for example, that Constantine visited the hot baths shortly before his own illness and death. ${ }^{35}$ So was Fausta sick when she took to her hot bath, with the result that it was her illness rather than the heat which overcame her? Perhaps. Yet a darker possibility suggests itself also in so far as hot baths feature prominently among the advice which was often given to women on how to induce abortion.

The 2nd-century physician Soranus, who studied at Alexandria in Egypt but practised at Rome itself, has left us a valuable work whose title sufficiently explains its contents, his Gynaecology. ${ }^{36}$ Soranus was one of the most highly reputed of ancient medical authorities, and enjoyed great popularity in the West during late antiquity, particularly in North Africa. He continued to be consulted into the 16 th century even. In his Gynaecology Soranus discusses various methods of contraception and abortion at some length, but sums up his basic theory thus (Gyn.1.61):

For such of these things [drugs] as are styptic, clogging, and cooling cause the orifice of the uterus to shut before the time of coitus and do not let the seed pass into its fundus. Such, however, as are hot and irritating, not only do not allow the seed of the man to remain in the cavity of the uterus, but draw forth as well another fluid from it. ${ }^{37}$

Cold causes the mouth of the uterus to shut, assisting thereby at contraception, but heat causes the uterus to evacuate its contents, assisting thereby at abortion. It is for this reason that baths, which are understood to be hot baths, although not too hot, feature so prominently in his advice on how to induce abortion. The patient is advised (Gyn. 1.64):

She should use diuretic concoctions ... bathing daily in sweet water which is not too hot, lingering in the baths and drinking first a little wine and living on pungent food. If this is without effect, one must also treat locally by having her sit in a bath of a decoction of linseed, fenugreek, mallow, marsh-mallow, and wormwood.

The advice continues a little later (Gyn. 1.65):

For a woman who intends to have an abortion, it is necessary for two or three days beforehand to take protracted baths, little food and to use softening vaginal suppositories; . . . But if a woman reacts unfavourably to venesection and is languid, one must first relax the parts by means of sitz-baths, full baths, softening vaginal suppositories ... And she who intends to apply these things should be bathed beforehand or made to relax by sitz-baths; and if after some time she brings forth nothing, she should again be relaxed by sitz-baths and for the second time a suppository should be applied.

It seems possible, therefore, that Fausta took to her hot bath as part of an attempt to induce an abortion. Yet abortion was often fatal. Obviously so for the unborn child, but often for the mother also, even in the best of 
circumstances. It is reported, for example, that the emperor Domitian (81-96) seduced his niece Julia, and was the cause of her death, therefore, when he forced her to have an abortion. ${ }^{38}$ Julia should have been able to afford the best medical advice of her day, but death still occurred. Indeed, it was the absence of effective contraception, combined with the dangers of abortion, that led to the widespread practice by which unwanted children were simply abandoned, either to die or to be rescued by strangers. ${ }^{39}$ Many of the church fathers regarded abortion as attempted suicide even. ${ }^{40}$ In this case, however, it was unthinkable that Fausta should continue her pregnancy and abandon her child, as there was always the possibility that he or she would one day return and lay claim to the throne. Dynastic considerations required that Fausta should have an abortion, despite the risk to her person which this inevitably entailed. Hence this interpretation of events, that Fausta died during an attempted abortion, merits serious consideration because it explains not only the unusual manner of Fausta's death, in a hot bath, but the very fact of her death also. More importantly, though, it is in perfect accord with the claims that Fausta had had a sexual relationship with Crispus, whether willingly or not. There seems a strong possibility that an unwanted pregnancy would have resulted from such a relationship. For Fausta was perfectly healthy in this regard, having given birth to at least five children in the ten years before her death, and ancient forms of contraception were not particular reliable. As for Crispus, we know that he was fertile also, because his wife Helena had given birth in 322 , and may have been expecting again in 324 also. ${ }^{41}$ It is my argument, therefore, that Fausta was pregnant by Crispus, and died in her bath when an attempt to induce abortion went fatally wrong.

So how does this change our understanding of all that went before Fausta's death? Constantine cannot be held directly responsible for her death in so far as he did not order her execution as such. However, the very sequence of events, the death of Crispus followed by that of Fausta, suggests that Constantine had discovered what had happened between Crispus and Fausta, or what was alleged to have happened, and that he had forced her to have an abortion rather than that she had undergone it willingly in an attempt to destroy the evidence of her guilt. Concealment, or further deceit, was no longer possible by the time that she died. This explanation contributes towards the solution of another problem also. How did Constantine learn of the alleged adultery between Crispus and Fausta? Sidonius Apollinaris seems to claim that Ablabius had played a role in revealing his wife's adultery to Constantine, but this only sets the 
question a stage further back in time. How did Ablabius himself learn of this adultery? One assumes, if Crispus and Fausta really did have an affair, that they were as discreet as possible and took every measure to conceal their relationship. However, the situation would have become much more difficult once Fausta became pregnant, particularly if she was unwilling to undergo a life-threatening abortion. It seems probable, therefore, that it was her pregnancy which brought Fausta's adultery into the open. There came a time when her physical condition gave rise to rumours among her private staff, these reached Ablabius, and he reported them to Constantine. This assumes, of course, that it was obvious to those involved that Constantine could not have been responsible if Fausta really were pregnant, that is, that he must have been away from Fausta long enough for all to realize that this could not be so. However, our sources are quite clear that something did happen between Crispus and Fausta, whether an affair or the rape of Fausta by Crispus, such as would not have happened, presumably, had Constantine been at hand. So the present interpretation requires little more than our sources themselves demand. Constantine was away from Fausta for several months, at the end of which time rumours were circulating that she and Crispus were having an affair, rumours which had originated with the suspicions in some quarters that she may have been pregnant. Constantine was informed, and questioned Fausta upon his return. She confessed that she was indeed pregnant, but claimed, truthfully perhaps, that Crispus had forced himself upon her. Hence Constantine had Crispus punished, following which he forced Fausta to proceed with an abortion, in the course of which she died.

Strictly speaking, therefore, Fausta died by accident, and Constantine can be absolved of guilt in this matter in so far as he had not intended her death. Yet as far as Christian teaching was concerned, this made little difference. From a Christian point of view, he remained responsible not only for her death, but for the death of her unborn child also. ${ }^{42}$ Hence Constantine had no choice but to conceal as best he could the real circumstances of her death, assuming, that is, that he wished to minimize the damage to his reputation as a Christian leader. There was also his personal pride to be taken into account. He hardly wanted to confirm to all and sundry that he had been made a cuckold, and this by his own son. If the fact that Fausta had died during an attempted abortion had escaped, pagan tradition would have rejoiced to recount this extra piece of scandal, if for no other reason than that it would seem to confirm the rumour that Fausta had been engaged in an illicit 
relationship. However, this does not seem to have happened. Constantine managed, with commendable efficiency, to keep a lid on the worst aspects of this affair. How did he do this? Enter Helena. What was her role in these events? Clearly, she must have done something suspicious at this time for the tradition to grow that she was responsible for Fausta's death. One suspects, though, that it was Constantine who sought her out and asked her to help deal with Fausta, rather than that she had sought him out in order to complain about Fausta. Doubtless there was hostility between Fausta and Helena, exactly as our sources allege, but it is possible that this was due more to Helena's role as Constantine's agent, and her attempts to persuade Fausta to proceed with an abortion, than any other reason. It is my argument, therefore, that the surviving tradition concerning Helena's role in Fausta's death depends more on external observation of the comings and goings at the palace rather than any genuine inside knowledge of the cause of all this activity. It was noted, perhaps, that Constantine had some unusual private meetings with his mother, and that she herself was greatly distressed. It was noted also that the two imperial ladies had become openly hostile towards each other. Then Fausta died in unusual circumstances, and no official explanation was forthcoming. Two and two were added to make five, and Helena was blamed for Fausta's death. In reality, though, she was no more than Constantine's confidential agent, chosen first to persuade Fausta to have an abortion, and then to act as her assistant during the fatal procedure itself. ${ }^{43}$ It was in this manner, therefore, that Constantine sought to minimize public knowledge of this whole sordid affair, by entrusting his mother with the more sensitive roles. ${ }^{44}$ It is little wonder that she felt the need to go on pilgrimage to the Holy Land shortly thereafter, probably in autumn $326 .^{45}$

It is appropriate at this point to comment in brief upon the death of Crispus also, concerning which two facts alone emerge, the location and means of the same. Writing c.391, the pagan historian Ammianus Marcellinus (14.11.20) let slip that Crispus was put to death at Pola on the Istrian peninsula. This is an important piece of information. For Pola was such an out-of-the-way place that Crispus must have had a particular reason to be there. It is generally accepted that Fausta died at Rome itself, and often held that Crispus normally resided at Trier in Germany. ${ }^{46}$ So how did he end up at Pola? It must itself have been his final destination, or the final stop on his journey to another location nearby, to one of the offshore islands perhaps. He could not have arrived there accidentally while on a journey from one imperial capital to 
another. ${ }^{47}$ Nor was this an important military zone such as might well have required his presence otherwise. Hence the best explanation for his presence at such a remote location is that he had been exiled there, or that he was on his way to exile on one of the nearby islands. ${ }^{48}$ So what sort of crimes merited such punishment? One notes that Constantine sentenced a senator, Ceionius Rufius Albinus, to exile on a charge of adultery at about this time also. ${ }^{49}$ Whether this is relevant to Crispus' own fate remains unclear, but it is important to note that Constantine considered exile an appropriate punishment for adultery, at least as far as the highest social classes were concerned. Hence the location of Crispus at his death, in a region to whose islands exiles were often sent, lends some support to the tradition that he had been convicted of adultery, and exiled as a result.

Let us turn next to the means of his death. Sidonius Apollinaris alone records that he died of poison, and in so far as no other source contradicts him in this, and his claim concerning Fausta's death, that she died in a hot bath, is supported by several other sources also, there is no cause to doubt his testimony here. Crispus was poisoned. This is important in that poison was not an official means of execution, which points to suicide by Crispus. ${ }^{50}$ Crispus, it would seem, killed himself, in despair perhaps, or in order to pre-empt the execution which he feared was his destined lot, whether immediately at the end of his journey or at some later point in time. Important exiles were at the mercy always of those factions at court which feared the return to influence of their enemies once more, and sought, therefore, to achieve their more permanent end. The elder Licinius had been exiled to Thessalonica following his defeat in 324, but Constantine had him killed shortly thereafter, despite an oath to preserve his life. ${ }^{51}$ In 354 Constantius II sentenced his cousin Gallus to exile only, but senior courtiers soon persuaded him to order his execution also, and even contrived to prevent a second order countermanding this execution from reaching its destination in time. ${ }^{52}$ Crispus seems to have realized that his death was only a matter of time, and acted accordingly.

\section{An overlooked allusion to the death of Fausta}

The Historia Augusta charts the lives and reigns of the Roman emperors from Hadrian, who began to rule in 117, to Carinus, who was killed in 285 , although its text has not survived for the period 244 to 260 . It 
professes to be the work of six different authors writing during the reigns of Diocletian (284-305), Constantius I (305-6), and Constantine I (306-37), but there is general agreement now that it was really written by one author only, writing at the end of the 4th or the beginning of the 5th century..$^{53}$ Its value as a historical source deteriorates as it progresses from Hadrian to Carinus, and although it begins almost as trustworthy biography, its accounts of the late 3rd-century emperors are nearly completely fictitious. This is certainly true of its account of the emperor Carinus which is of most interest to us here.

Carinus was the eldest son of the emperor Carus who rose to power in late 282 following the assassination of his predecessor Probus near Sirmium in Pannonia. Carus then elevated Carinus to the rank of Caesar and left him in command of the Western Empire while he set out on an expedition against the Persians together with his youngest son Numerianus, Caesar also. The expedition was successful, and they captured the Persian capital Ctesiphon. Shortly afterwards, however, Carus was killed by lightning, and Numerianus succeeded him. ${ }^{54} \mathrm{He}$ was assassinated while leading his army home, and Diocletian, the commander of his bodyguard, succeeded him in turn. When news of these events reached the West, Carinus had first to put down a military revolt in northern Italy, and readied himself then to confront his rival Diocletian. In the spring of 285 their armies met near the river Margus in Moesia, and Diocletian emerged victorious.

This is a summary of what little is known about Carinus and his family, most of which comes from various 4th-century epitomators. These same sources all agree that Carinus lived a life of lust and vindictiveness, and that he lost his battle against Diocletian because his troops deserted him in disgust at this lifestyle. ${ }^{55}$ Of most relevance to us here, however, is an anecdote concerning his decadence which occurs in the Historia Augusta alone. Following a description of his bejewelled finery, his luxurious banquets, and his custom of showering his banqueting-halls and bedrooms with roses from Milan, Carinus' bathing habits are described as follows (V. Cari 17):

The baths which he [Carinus] used were as cold as the air of rooms that are under the ground, and his plunge-baths were always cooled by means of snow. Once, when he came in the winter to a certain place in which the spring-water was very tepid - its wonted natural temperature during the winter - and he had bathed in it in the pool, he shouted to the bath-attendants, it is said, 'This is water for a woman that you have given me'; and this is reported as his most famous saying. When his father heard of all that he did, he exclaimed, ' $\mathrm{He}$ is no son of mine', and at last he determined to appoint 
Constantius - afterwards made Caesar but at that time serving as governor of Dalmatia in the place of Carinus, for the reason that no one even then seemed to be better, and he even planned, as Onesimus relates, to put Carinus to death. ${ }^{56}$

With the possible exception of the reference to the position of Constantius I as governor of Dalmatia, these allegations are obviously and totally fictitious. But what was the purpose of this unhistorical nonsense? It is generally accepted now that many of the fictitious claims within the Historia Augusta allude to various 4th-century events. ${ }^{57}$ It has been argued, for example, that its account of the emperor Elagabalus $(218-22)$ consists in large part of a satire on Constantine $I{ }^{58}$ It has even been claimed that 'Elagabalus' unsuccessful attempt to murder his adopted son Alexander Severus recalls Constantine's murder of his son Crispus'. ${ }^{59}$ It is not unreasonable, therefore, to seek a similar allusion in the above passage, and there is a strong case to be made that it alludes to the deaths of Crispus and Fausta in particular.

Firstly, the claim by Carinus that the water in the pool where he was bathing, which happened to be too warm for his liking, was 'water for a woman' (aqua muliebris) reminds one of the claim that Fausta died in an overheated bath. Indeed, it is difficult to make sense of this passage otherwise. In so far as mixed bathing was common practice in the public baths, and there is no evidence that baths were maintained at different temperatures for women, the description of water which was too warm as 'water fit for a woman' seems to make little sense in and of itself. ${ }^{60}$ Secondly, Carus' alleged exclamation concerning Carinus, ' $\mathrm{He}$ is no son of mine', taken literally at least, raises the question of illegitimacy and adultery. At one level this reads as an accusation by Carinus against his wife that she had committed adultery and passed off another man's child as his son, reminiscent of the tradition that Fausta was guilty of adultery. ${ }^{61}$ Finally, the claim that Carus wished to put to death Carinus, his eldest son and Caesar, cannot but remind one that Constantine put to death Crispus, his eldest son and Caesar also, or so the story went. It is my argument, therefore, that the author of the Historia Augusta had before him a source which included an account of the controversy surrounding the deaths of Crispus and Fausta, and wove different elements of this account into his narrative concerning Carinus. He did not intend an exact analogy, but expected rather that the very combination of these elements would be enough for his reader to understand the subject of his allusion. Furthermore, there is a strong similarity between the vices and excesses which he had attributed to Elagabalus earlier and those which he attributes 
to Carinus here. ${ }^{62}$ Why is this? The fact that his life of Elagabalus was a satire on Constantine I, and that his life of Carinus reminds us of Elagabalus once more is surely important. The author is trying to signal to us that he has returned to the subject of Constantine once more in his life of Carinus, and that it is to his reign which we must turn again also if we are to hope to understand the real significance of his words.

In conclusion, therefore, Constantine has been unfairly blamed for the execution of his wife and eldest son, neither of whom he had wished to see dead. The best explanation for the unusual circumstances of Fausta at her death, in a hot bath, is that she died by accident during an attempted abortion. This ties in with the allegation that she was guilty of adultery with Crispus. As for Crispus, he was sentenced to exile, a punishment which points towards his conviction of adultery also. $\mathrm{He}$ then committed suicide. Constantine did his best to cover up this whole sordid mess. He managed to conceal the details of Fausta's death, that she had died during an attempted abortion, because it had taken place in the privacy of the imperial bathroom when Fausta was attended only by the other imperial ladies, not least her mother-in-law Helena. He could not, however, conceal the fact that she had died in a hot bath, which information is surely due to the servants who had prepared the same. Nor could he prevent people from assuming, as a result of their close succession, that the deaths of Crispus and Fausta must have been related, an assumption fuelled by a palace rumour that the pair had committed adultery together. Indeed, the veil of secrecy with which he surrounded the death of Fausta in particular only served to confirm people's worst suspicions, that he must have ordered their executions. He further reinforced these suspicions by condemning the memory of both, or by allowing this condemnation to stand even after their deaths. This reflected merely his continuing anger at their adultery together, and at the situation in which their untimely deaths had placed him, but it encouraged people to assume the worst. ${ }^{63}$ Together with his apparent refusal to justify 'his' actions, since, of course, he did not regard himself as responsible for either death, one a suicide, the other an accident, this left a vacuum which rumour and innuendo strove to fill. In the end, therefore, Constantine proved the worst enemy of his own reputation.

\section{NOTES}

1. For full references, see A. H. M. Jones, J. R. Martindale, and J. Morris, The Prosopography of the Later Roman Empire I: $A D$ 260-395 (Cambridge, 1971), 325-6. Her full name is known only from coins (n. 3). 
2. See T. D. Barnes, The New Empire of Diocletian and Constantine (Cambridge, Mass., 1982), 42-3.

3. See P. Bruun, The Roman Imperial Coinage VII: Constantine and Licinius AD 313-37 (London, 1966), 116, 137, 203, 263-4, 325-6, 383, 447, 475, 514-15, 551, 612-13, 647, 709.

4. In his Liber de Caesaribus composed c.361, Aurelius Victor notes only that (De Caes. 41.11), 'When the eldest of these [Constantine's children] had died on the orders of his father, suddenly Calocerus, commander of the imperial camel herd, insanely seized the island of Cyprus and pretended to rule', with no mention of Fausta. In his Breviarium composed c.369, Eutropius claims that Constantine became arrogant with the result that (Brev. 10.6) 'First he persecuted his relatives and killed his son, an outstanding man, and his sister's son, subsequently his wife and afterwards numerous friends'. Writing c.380, Jerome notes in his Chronicle for 325, 'Crispus, the son of Constantine, and Licinius Junior, the son of Licinius and Constantia, Constantine's sister, are most cruelly killed', but misdates the death of Fausta to 328, stating simply, 'Constantine kills his wife Fausta'. The anonymous compiler of the first recension of the Consularia Constantinopolitana, writing c.388, dates the death of Crispus to 326, stating only, 'Crispus was killed'. He dates the death of Licinius Junior to 325, but does not mention Fausta at all. Finally, the ecclesiastical historian Orosius, writing c.417, claims, following a brief mention of the Arian heresy and the Council of Nicaea in 325, that (Adv. Pag. 7.26) 'Constantine turned the sword of vengeange and the punishment destined for the impious against even his close relatives. For he killed his own son, Crispus, and his sister's son, Licinius.'

5. In general, see Barnes, 'The Epitome de Caesaribus and Its Sources', CPh 71 (1976), 258-68.

6. In general, see A. E. Nobbs, 'Philostorgius' View of the Past' in G. Clarke, B. Croke, A. E. Nobbs, and R. Mortley (edd.), Reading the Past in Late Antiquity (Rushcutters Bay, 1990), 251-64.

7. From E. Walford, The Ecclesiastical History of Sozomen . . . also the Ecclesiastical History of Philostorgius as Epitomized by Photius (London, 1855), 435.

8. In general, see J. Harries, Sidonius Apollinaris and the Fall of Rome AD 407-485 (Oxford, 1994).

9. From the Loeb translation by W. B. Anderson, Sidonius: Poems and Letters II (Cambridge, Mass., 1965), 197. The description of an age 'of Nero's pattern' refers to the claims by earlier sources that the emperor Nero (54-68) had had an incestuous relationship with his natural mother Agrippina (Tac. Ann. 14.2; Suet. Nero 28.2), alluding thereby to the claim that Crispus had enjoyed a similar relationship also with his stepmother Fausta.

10. In general, see R. T. Ridley, 'Zosimus the Historian', BZ 65 (1972), 277-302.

11. From R. T. Ridley, Zosimus' New History: a Translation with Commentary (Canberra, 1982), $36-7$.

12. See S. N. C. Lieu and D. Montserrat (edd.), From Constantine to Fulian: Pagan and Byzantine Views. A Source History (London, 1996), 210-62, for a full discussion of this text, and the translation which I have followed here, 242.

13. In general, see B. Bleckmann, 'Die Chronik des Johannes Zonaras und eine pagane Quelle zur Geschichte Konstantins', Historia 40 (1991), 343-65.

14. From the translation by H. A. Pohlsander, 'Crispus: Brilliant Career and Tragic End', Historia 33 (1984), 79-106, at 101.

15. Crispus' name was erased from CIL II.4107, III.7172, V.8030, IX.6386a, X.517, together with that of Fausta from CIL X.678.

16. See Barnes, 'The Editions of Eusebius' Ecclesiastical History', GRBS 21 (1980), 191-201, at 197.

17. It is a sad comment on our age that it seems so incomprehensible to many that anyone should ever have been punished just for adultery. Conspiracies or other political machinations have to be discovered as the 'real' causes of events. See A. Ferrill, 'Augustus and His Daughter: a Modern Myth', in C. Deroux (ed.), Studies in Latin Literature and Roman History II (Collection Latomus 168: Brussels, 1980), 332-46, for a similar dispute concerning the 'real' reason for the exile by Augustus of his daughter Julia to the island of Pandateria in 2 B.C. A recent exception is G. Marasco, 'Constantino e le uccisioni di Crispo e Fausta (326DC)', Rivista di Filologia e di Istruzione Classica 121 (1993), 297-317, who argues that Crispus and Fausta were executed not so much for adultery, but for incest; I thank Prof. T. G. Elliott for drawing this last to my attention.

18. P. Guthrie, 'The Execution of Crispus', Phoenix 20 (1966), 325-31. 
19. Pohlsander, art. cit. (n. 14), 105-6.

20. Pan. Lat. 7.4 refers to Minervina, the mother of Crispus, as Constantine's wife, which seems proof that he was legitimate. In general, see Barnes, op. cit. (n. 2), 36, 42-3; also, J. E. Grubbs, Law and Family in Late Antiquity: the Emperor Constantine's Marriage Legislation (Oxford, 1995), 306-7.

21. N. J. E. Austin, 'Constantine and Crispus', Acta Classica 23 (1980), 133-8.

22. J. W. Drijvers, 'Flavia Maxima Fausta: Some Remarks', Historia 41 (1992), 500-6, at 505.

23. Barnes, Constantine and Eusebius (Cambridge, Mass., 1981), 220.

24. So Pohlsander, art. cit. (n. 14), 101, claims of the relevant passages in Zosimus and Zonaras, that 'the Phaedra-and-Hippolytus motif is obvious and certainly raises doubts about the veracity of this account'. Yet similar such relationships did sometimes occur, as in the case of Antonina, the wife of the 6th-century general Belisarius, who had an affair with their adopted son Theodosius (Proc. Anec. 1.14-30). See also P. A. Watson, Ancient Stepmothers: Myth, Misogyny, and Reality (Leiden, 1995), 136-9.

25. In general, see F. Paschoud, 'Zosime 2.29 et la version paienne de la conversion de Constantin', Historia 20 (1971), 334-53. See also G. Fowden, 'The Last Days of Constantine:

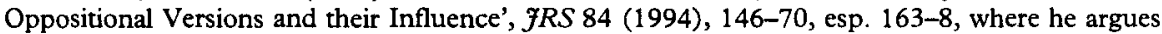
that, in this instance, Zosimus combined Eunapius' text with the fictitious Actus Silvestri.

26. Drijvers, art. cit. (n. 22), 505.

27. E.g., J. Burckhardt, The Age of Constantine the Great (London, 1949: a translation by $M$. Hadas of the German original), 283, alleges that Constantine had Fausta 'drowned in her bath'; J. P. V. D. Balsdon, Roman Women: their History and Habits (London, 1962), 170, claims that 'she was roasted - or scalded - to death in the baths'; Barnes, op. cit. (n. 23), 221, claims that she 'suffocated in the steam'; M. Grant, The Emperor Constantine (London, 1993), 114, keeps an open mind, claiming that 'he [Constantine] had her immersed in a scalding bath, or suffocated in a deliberately over-heated steam-room'.

28. J.-L. Desnier, 'Zosime II, 29 et la mort de Fausta,' $B A G B$ (1987), 297-309, at 305.

29. In general, see R. MacMullen, 'Judicial Savagery in the Roman Empire', Chiron 16 (1986), $147-66$.

30. Grubbs, op. cit. (n. 20), 216-21.

31. Barnes, op. cit. (n. 23), 221, opts strongly for suicide, as he continues to do in $\mathcal{F E H} 44$ (1993), 293, reviewing J. W. Drijvers, Helena Augusta: the Mother of Constantine the Great and the Legend of Her Finding of the True Cross (Leiden, 1992), who accepts (60) that Fausta was executed.

32. Amm. 28.1.47.

33. From the translation by B. Jackson, Nicene and Post-Nicene Fathers III.

34. See F. Yegül, Baths and Bathing in Classical Antiquity (Cambridge, Mass., 1992), 352-5.

35. There is some dispute over the exact location of these baths. Eusebius (VC 4.61) claims that Constantine visited the hot baths of his own city, by which he must mean Constantinople, while Zonaras (Epit. 13.4.25-27) claims that he sailed across to visit hot springs at Soteropolis in Asia Minor. It is possible that he visited both.

36. On the life, works, and nachleben of Soranus, see A. E. Hanson, 'Soranus of Ephesus: Methodicorum Princeps', in W. Haase and H. Temporini (edd.), ANRW II.37.2 (Berlin, 1994), 968-1075.

37. The following passages of translation are from O. Temkin, Soranus' Gynecology (Baltimore, 1956).

38. Suet. Domit. 22.

39. See E. Eyben, 'Family Planning in Graeco-Roman Antiquity', AncSoc 11/12 (1980/81), 582; also, W. V. Harris, 'Child-Exposure in the Roman Empire', $Y R S ~ 84$ (1994), 1-22.

40. E.g., Jerome, Ep. 22.13; Basil, Ep. 188 Canon 2.

41. Barnes, op. cit. (n. 2), 44, on C.Th. 9.38.1 and Porfyrius, Carm. 10.

42. Eyben, art. cit. (n. 39), 62-74.

43. A number of other imperial ladies were probably available also to help Helena if she so required, including Eutropia, Fausta's own mother, and Constantia, Constantine's sister. On the last, see now H. A. Pohlsander, 'Constantia', AncSoc 25 (1994), 151-67.

44. Imperial ladies, even Christians, were no less likely to be aware of various methods of contraception or abortion than any other group. E.g., Eusebia, wife of Constantius II (337-61), was alleged to have tricked Helena, the wife of Julian Caesar, into drinking a potion that caused her to 
miscarry (Amm. 16.10.18). Theodora, the wife of Justinian I (527-65), was alleged to have had many abortions during her years as an 'actress' (Proc. Anec. 9.19, 17.16).

45. Eus, VC 3.42-6. Grant, op. cit. (n. 27), 115, refers to 'Constantine's dispatch of his mother Helena to the Holy Land, in the hope of expiation'.

46. On Fausta's location, see, e.g., Barnes, op. cit. (n. 23), 221; Drijvers, art. cit. (n. 22), 506. On Crispus' journeys and residence, see Barnes, op. cit. (n. 2), 83-4.

47. The evidence for the imperial journeys of the period $283-337$ has been collected by Barnes, op. cit. (n. 2), but there is no evidence that anyone else happened ever to visit Pola other than Crispus. The same is true of the period 337-61, on which see Barnes, Athanasius and Constantius: Theology and Politics in the Constantinian Empire (Cambridge, Mass., 1993), 218-28, with one exception, the ex-Caesar Gallus who passed near Pola on his way to exile at Flanona on a nearby island (Amm. 14.11.20; Cons. Constant. s.a. 354; Soc. HE 2.34).

48. Other 4th-century exiles to the Dalmatian islands include the ex-magister officiorum Florentius in 361 (Amm. 22.3.6), and the ex-proconsul of Africa Hymetius c.371 (Amm. 28.1.23).

49. See Barnes, 'Two Senators Under Constantine', $7 R S 64$ (1975), 40-9, on Firm. Mat. Math. 2.29.10.

50. So Pohlsander, art. cit. (n. 14), 104, argues that Crispus was 'confronted by an imperial emissary and allowed to choose the means of death'.

51. Eutr. Brev. 10.6.1; Epit. 41.7; Zos. HN 2.28. The claim that Licinius was trying to raise a revolt once more, Soc. $H E$ 1.4, seems simply a propaganda effort by Constantine, or his flatterers, to justify this crime.

52. Philost. HE 4.1; Art. Pass. 15.

53. See, e.g., P. White, 'The Authorship of the Historia Augusta', GRS 57 (1967), 115-33; T. Honoré, 'Scriptor Historiae Augustae', $\exists R S 77$ (1987), 156-76. The Historia Augusta is usually dated by means of its perceived dependency upon a variety of late antique texts which include works by Eunapius. Claudian, and Vegetius. Unfortunately, though, the dates of composition of many of these works are themselves subject to dispute. English-speaking scholars generally date its composition c. 395 .

54. See H. W. Bird, 'Diocletian and the Deaths of Carus, Numerian and Carinus', Latomus 35 (1976), 123-32.

55. Aur. Vict. De Caes. 39.11; Eutr. Brev. 9.20; Epit. 37.7-8.

56. From the Loeb translation by D. Magie, The Scriptores Historiae Augustae III (Cambridge, Mass., 1932), 443-5.

57. See, e.g., R. Syme, Ammianus and the Historia Augusta (Oxford, 1968), passim.

58. See R. Turcan, 'Héliogabale précurseur de Constantin?', $B A G B(1988), 38-52$; G. Fowden, 'Constantine's Porphyry Column: the Earliest Literary Allusion', $f R S 81$ (1991), 119-31.

59. Fowden, art. cit. (n. 58), 120, on V. Heliogab. 13-14.

60. That prostitutes often entertained their clients at the baths is sufficient proof that male and female could tolerate the same water. In general, see R. Bowen Ward, 'Women in Roman Baths', HThR 85 (1992), 125-47; also C. Dauphin, 'Brothels, Baths, and Babes: Prostitution in the Byzantine Holy Land', Classics Ireland 3 (1996), 47-72.

61. See A. Chastagnol, 'Études sur la Vita Cari IX: Non est meus', in G. Bonamente and F. Paschoud (edd.), Historiae Augustae Colloquium Genevense: Atti dei Convegni sulla Historia Augusta II (Bari, 1994), 89-99, esp. 92, on adultery, and 98, on Crispus and Fausta.

62. See Chastagnol, 'Étude sur la Vita Cari VIII: Carin et Elagabal', in F. Straub (ed.), Bonner Historia-Augusta-Colloquium 1979-81 (Bonn, 1985), 99-113.

63. Pohlsander, art. cit. (n. 14), 103, rejects the possibility that Fausta died by accident in her bath on the basis that Constantine did not restore her memory, or honour her with 'a splendid funeral, orations, and monuments'. But accidents continue to happen even to people deep in disgrace. 